UDC 330.322

DOI https://doi.org/10.32849/2663-5313/2020.6.04

Oksana Hnativ,

Candidate of Law Sciences,

Associate Professor at the Department of Civil Law and Procedure

of Ivan Franko National University of Lviv

\title{
THE EFFECTIVENESS OF LEGAL REGULATION AS A WAY TO ATTRACTING FOREIGN INVESTMENT TO UKRAINE
}

In Ukraine it is quite common to hear about the need to improve the investment climate. Investors, regardless of whether they are national or foreign, would not risk investing funds or other investments in the Ukrainian economy only through the assurances of the governmental agencies at international economic forums. The improvement of the investment climate should be evidenced by the real actions of public authorities. First of all, it is necessary to ensure the legal regulation of investment relations, including those with the participation of foreign investors, effectiveness.

The presence of effective legal regulation of investment relations is a key to attracting foreign investment, as it is intended to ensure the rights and legitimate interests of foreign investors, as well as their protection. Legal regulation effectiveness involves improving the quality of legal regulations governing investment relations. Excessive over-regulation of economic relations creates obstacles to the emergence of new types thereof, inhibits investment processes. Stability is a component of the legal regulation of investment relations effectiveness. Legal regulations should ensure long-term governing of investment relations without hindering their development. Selective changes in legislation in general and in investment relations in particular have a negative impact on economic relations, which causes the outflow of foreign and domestic investment, as investors do not feel the legal safeguards of investment and its protection. Gradual and systematic reform of not only investment, but also tax, land, civil, business legislation of Ukraine can ensure its sustainability and progress.

Legal regulations governing investment relations shall ensure the reality and effectiveness of investors' rights and legitimate interests judicial protection. These measures altogether can provide an "attractive" investment climate in Ukraine. In the absence of effective legal regulation, the state is not in a position to guarantee the proper conditions for conducting investment activity, which is crucial for the investment attractiveness of the state, as well as for the sustainable development of its economy.

Key words: investment climate, effective legal regulation, investment relations, foreign investments, investors' rights and legitimate interests.

Introduction. As a socio-political entity, the state needs financial resources, in particular, to fulfill its functions. The development of the economy should ensure a continuous flow of such resources into the state's treasury. The fact that the funds are paid to the budget only by paying taxes indicates the ineffective regulation of economic relations, including those with participation of the state as the property owner.

Attraction of investments, in particular, foreign ones, is one of the most effective ways to ensure a sustainable development of the state's economy. Ukraine is the state with economy in transition, i.e. it is in the process of economic changes, which should contribute to the departure from the command-andcontrol system of economic management and establishing market relations. This points to the urgent need to attract investment, to implement new investment projects to overcome the crisis, including the current one caused by the worldwide COVID-19 pandemic.

In this regard, the most important component of the state's investment attractiveness is the effective legal regulation of investment relations.

The studies of such national scientists as O. Bandurka, V. Kaforskyi, V. Kossak, O. Vinnyk and others are devoted to the research of investment relations in Ukraine. However, the subject of their study was the substance and legal status of participants in investment relations, rather than the effectiveness of the latter's legal regulation in general.

1. The concept of effectiveness in the legal regulation of relations with the participation of foreign investors

The term "effectiveness" is used mostly in protective legal relations, while defining ways to protect the rights and legitimate interests of the individual. Thus, Art. 13 of the Con- 
vention for the Protection of Human Rights and Fundamental Freedoms of 04 November 1950 [1] enshrines a person's right to an effective remedy. The effectiveness of human rights protection method has been repeatedly outlined by the European Court of Human Rights and the current Supreme Court. In particular, in its Judgment of 4 June 2019 in Case No. 916/3156/17 [2], the Grand Chamber of the Supreme Court emphasized that a right or interest should be protected by a court in a manner that is effective, that is, consistent with the content of the relevant right or interest, the nature of the violation, non-recognition or challenge thereof, and the consequences of such acts. However, it should be noted that the European Court of Human Rights, in its judgment of 15 November 1996 Chahal v. The United Kingdom [3], stated that the provision of Art. 13 of the Convention for the Protection of Human Rights and Fundamental Freedoms guarantees, at the national level, effective remedies for the enjoyment of the rights and freedoms that it protects, regardless of the content of interpretation in a state's legal system.

At the same time, according to V. Tsikalo, effectiveness should be considered as a feature of freedom of rights, in particular, corporate exercise [4, p. 193]. In my opinion, effective legal regulation directly affects both the exercise and the protection of the rights and legitimate interests of foreign investors.

As A. Melnyk rightly points out, the effectiveness of legal regulation is a productive characteristic of its action, which testifies to the ability to solve relevant socio-legal problems [5, p. 12]. Effectiveness is a category that allows to determine the level of functionality of legal regulation mechanism in its dynamics $[6$, p. 8].

It should be concluded from the above that legal regulation should be implemented in the long run. The post-Soviet states are characterized by the over-regulation of social relations, when the legislator tries to consolidate all possible concepts without defining their essential features, as well as to regulate these relations at the moment of adoption of a normative act, which further impedes the development of the relations. An example is the situation with the regulation of digital currency. Art. 15 of the Law of Ukraine "On Payment Systems and Funds Transfer in Ukraine" of 5 April 2001 [7] stipulates that only a bank can be an digital currency issuer. Thus, the legislator left virtually "outlaw" non-banking institutions that issue digital currency, such as PayPal, which successfully operate worldwide.
2. Planning and forecasting as a prerequisite for effective legal regulation of investment relations

It is undeniable that the emergence of economic relations precedes their legal regulation. At the same time, planning and forecasting determine the main directions of economic, in particular investment, relations development and are intended to provide effective legal regulation of these relations. According to part 4 of Art. 9 of the Economic Code of Ukraine [8] the legal consolidation of state economic policy is carried out in the forecasts and programs of economic and social development of the state as a whole and its territorial-administrative units, in particular. The said reflects the economic development strategy. However, in view of the need for effective legal regulation of economic relations, the legislator shall ensure the logic of the lawmaking process in this area.

In order to choose an economic strategy and to consolidate it in legal acts, it is necessary to study the world economic processes (markets, investment-attractive industries, the use of innovative technologies, etc.), which, in turn, will allow to predict their impact on the national economy of Ukraine, the emergence of new economic relations, dynamics of development of existing ones, identification of possible risks, etc. On the basis of these forecasts, the strategy of economic development of the state, principles of implementation of economic policy are developed, and, as a consequence, the principles of private law entities interaction with the state in the sphere of economic policy implementation in the new conditions are outlined, in order to ensure sustainable development of the state and minimization of the negative effects of crisis phenomena. And as a result of choosing an economic strategy, the economic and social plans and programs provide the means of its implementation. In fact, the consistency of these actions will ensure the effective regulation of economic relations.

Economic forecasts should form the basis for identifying attractive areas of investment for economic activity, as well as facilities that require investment because of the inability of the state to provide for their own retrofitting or conversion. Comparison of economic forecasts concerning the world economy with the peculiarities of economic relations in the state would allow to identify and consolidate at the legislative level the principles of investment policy, which does not interfere with the development of new investment relations and, at the same time, provides protection to each of the participants of existing relations. 
3. Criteria for the legal regulation of investment relations effectiveness

When adopting investment legislation, the principle of proportionality shall be respected, in order to ensure that the interests of all investment entities are equally balanced. Violation of the principle of proportionality may lead to the excessive protection of one of the participants in the investment activity. Thus, due to fraudulent actions related to attracting direct investments from individuals in housing construction, only on December 15, 2005, changes were made to Art. 4 of the Law of Ukraine "On Investment Activity" of 18 September 1991 [9], under which investment in housing construction at the expense of nonstate funds can be made exclusively through specially created funds (construction financing funds, real estate funds, joint investment institutions), and also by issue of the target bonds of the enterprises, the fulfillment of obligations under which is carried out by the transfer of the object (part of the object) of housing construction; other ways of financing can be determined only by the laws of Ukraine.

Thus, when adopting (amending existing) regulations, it is necessary to identify possible risks (abuse) in the implementation of investments, including foreign ones, and to ensure the implementation of the principle of proportionality.

The next criterion for the effectiveness of legal public relations with the participation of foreign investors regulation is the investment legislation of Ukraine stability. Despite the fact that Art. 8 of the Law of Ukraine "On the Regime of Foreign Investment" of 19 March 1996 [10] contains safeguards for changes in legislation, their scope extends exclusively to changes in the safeguards of protection of foreign investments. At the same time, changes that affect investment activity and do not relate to safeguards for the protection of foreign investment are applied in the general manner prescribed by law. Changes to the tax legislation of Ukraine For can be an example. Thus, the Tax Code of Ukraine of 2 December 2010 came into force on 1 January 2011. On the contrary, in foreign states, the implementation of the new codes is gradual and takes a long period of time to make it possible to adapt to the new conditions of conducting business, including investment activity.

The principle of stability of investment legislation is closely linked to the principles of systematic and uniform legal regulation, graduality. Investment legislation of Ukraine is not represented by only one or two laws that directly determine the principles of investment activity, foreign investments. This is the uniform system of laws and regulations that ensure the effectiveness of legal regulation of investment activity in Ukraine. The mentioned system contains the Constitution of Ukraine, Civil, Economic, Tax, Customs Codes of Ukraine, Laws of Ukraine "On Investment Activity", "On the Regime of Foreign Investment", "On Public-Private Partnership" and others. It is obvious that the safeguards of change of legislation should not only extend to the change of the legislation on foreign investments protection.

In addition, the violation of the principle of systematicity is also reflected in the fact that the Law "On Public-Private Partnership was adopted on 1 July 2010 but the new Law of Ukraine "On Concession" came into force only on 3 October 2019. At the same time, the issue of coherence of the mentioned legal acts remains open.

Finally, the principles (rules) for conducting investment activities by foreign investors in Ukraine shall be clear and comprehensible, capable of securing the exercise of the rights of participants in investment activities and without creating obstacles to the emergence and development of new investment relations. An example of effective legal regulation is the Civil Code of France (Napoleon Code) of 1804. The majority of its regulations remains in force nowadays and continue to regulate public relations.

All in all, it should be noted that the adoption of laws in the context of coronavirus infection or other force majeure circumstances, also cannot be haphazard. An example is the Law of Ukraine "On Amendments to the Tax Code of Ukraine and Other Laws of Ukraine on Support of Taxpayers for the Period of Measures to Prevent the Occurrence and Spread of Coronavirus Disease (COVID-19)" of 17 March 2020 [11], which released the taxpayers from the payment of the land tax for the period from 1 March to 30 April 2020. On the contrary, the Law of Ukraine "On Amendments to Some Legislative Acts of Ukraine Aimed at Providing Additional Social and Economic Safeguards in Terms of the extension of Coronavirus Disease (COVID-19)" of 30March 2020 [12] ordered to pay the said tax for April. Such haste in adopting regulations adversely affects their quality and effectiveness.

\section{Conclusions}

Summarizing the above, it should be noted that the effectiveness of the investment relations legal regulation affects not only the protection, but also the exercise of the rights of all entities involved. In the absence of proper safeguards, foreign investors are not interested in investing into Ukrainian economy. At the same time, the legally enforced safeguards of foreign 
investments should concern both their implementation and protection. Effective legal regulation of investment relations aims to ensure the rights of foreign investors and their legitimate interests, as well as their protection, including in force majeure conditions.

\section{References:}

1. Convention for the Protection of Human Rights and Fundamental Freedoms: International Agreement, 4 November 1950. URL: https://zakon. rada.gov.ua/laws/show/995_004 [in Ukrainian].

2. Court case No 916/3156/17 as of 2019: URL: http://www.reyestr. court.gov.ua/Review/82424016 [in Ukrainian].

3. Chahal v. the United Kingdom, (22414/93) [1996] ECHR 54. URL: https://www. asylumlawdatabase.eu/sites/default/files/aldfiles/ Chahal_0.pdf [in Ukrainian].

4. Tsikalo V.I. Effectiveness in protecting corporate rights. Civil Law of Ukraine: New Challenges and Prospects for Development: Materials of XVIII Research Practice conf., ded 98th Birthday Anniversary. Dr. Of Laws, Prof., Cor.Member. USSR Academy of Sciences V. P. Maslov (Kharkiv, 28 February 2020). Kharkiv: Pravo, 2020. 480 p. P. 193-196 [in Ukrainian].

5. Melnyk O.M. Legal regulation and ways to increase its effectiveness: abstract. dissertation ... Cand. Of Laws: 12.00.01; NAS of Ukraine,
V.M. Koretskyi Institute of State and Law. Kiev, 2004. 20 p. [in Ukrainian].

6. Kurakin O.M. Analysis of the correlation between the category "legal regulation effectiveness" and related concepts. Current issues of domestic jurisprudence, 2016, № 2. P. 7-10 [in Ukrainian].

7. On Payment Systems and Funds Transfer in Ukraine: Law of Ukraine, 5April 2001. Office of the Verkhovna Rada of Ukraine. 2001. № 29. Art.137 [in Ukrainian].

8. Economic Code of Ukraine: Law of Ukraine, 16 January 2003. Office of the Verkhowna Rada of Ukraine. 2003. № 18, № 19-20, № 21-22. Art.144 [in Ukrainian].

9. On Investment Activity: Law of Ukraine, 18 September 1991. Office of the Verkhovna Rada of Ukraine, 1991, № 47, Art.646 [in Ukrainian].

10. On the Regime of Foreign Investment: Law of Ukraine, 19 березня 1996 року. Відомості Верховної Ради України. 1996. № 19. Art. 80 [in Ukrainian].

11. On Amendments to the Tax Code of Ukraine and Other Laws of Ukraine on Support of Taxpayers for the Period of Measures to Prevent the Occurrence and Spread of Coronavirus Disease (COVID-19): Law of Ukraine, 17 March 2020. URL: https://zakon. rada.gov.ua/laws/show/533-20 [in Ukrainian].

12. On Amendments to Some Legislative Acts of Ukraine Aimed at Providing Additional Social and Economic Safeguards in Terms of the extension of Coronavirus Disease (COVID-19): Law of Ukraine, 30 March 2020. URL: https://zakon.rada.gov.ua/ laws/show/540-20\#n6 [in Ukrainian].

Оксана Гнатів. Ефективність правового регулювання як запорука залучення іноземних інвестицій в Україну

В Украӥні досить часто можна почути про необхідність покращення інвестиційного клімату. Інвестори, незалежно від того, йдеться про начіональних чи іноземних, не ризикуватимуть вкладати кошти, інші інвестицї в економіку України лише через запевнення суб'єктів владних повноважень на міжнародних економічних форумах. Про покращення інвестиційного клімату повинні свідчити реальні дії органів державної влади. Насамперед необхідно забезпечити ефективність правового регулювання інвестиційних відносин, у тому числі за участю іноземних інвесторів.

Ефективне правове регулювання інвестииійних відносин є запорукою залучення іноземних інвестицій, оскільки покликане забезпечити здійснення прав та законних інтересів іноземних інвесторів, а також їх захист. Ефективність правового регулювання передбачає підвищення якості правових норм, які регулюють інвестиційні відносини. Надмірна зарегульованість економічних відносин створює перешкоди для виникнення нових їх видів, гальмує інвестииійні прочеси. Складником ефективності правового регулювання інвестиційних відносин є його стабільність. Норми права мали би забезпечити довгострокове регулювання інвестииійних відносин, не перешкоджаючи іхх розвитку. Вибіркова зміна законодавства в чілому та інвестиційних відносин зокрема негативно позначається на економічних відносинах, зумовлює відтік іноземних та начіональних інвестииій, оскільки інвестори не відчувають законодавчих гарантій здійснення та захисту інвестииій. Поступове й системне реформування не лише інвестиційного, а й податкового, земельного, иивільного, підприємницького законодавства Украйни має забезпечити його сталість та прогресивність.

Правові норми, які регулюють інвестииійні відносини, повинні забезпечувати реальність та ефективність судового захисту прав та законних інтересів інвесторів. Усе че в сукупності забезпечить «привабливий» інвестииійний клімат в Україні. За відсутності ефективного правового регулювання держава не здатна гарантувати належні умови провадження інвестиційної діяльності, що є визначальним для інвестиційної привабливості держави, а також сталого розвитку ї економіки.

Ключові слова: інвестиційний клімат, ефективне правове регулювання, інвестиційні відносини, іноземні інвестиції, права та законні інтереси інвесторів. 